\title{
Corporate Governance Practices in the Banking and Finance Sector: Perspectives from Bangladesh
}

\author{
Md. Nazmul Hossain \\ Raju Mohammad Kamrul Alam \\ RUDN University, Moscow, Russia \\ Palto Datta \\ Mark T. Jones \\ Centre for Innovative Leadership Navigation, UK
}

\begin{abstract}
Keywords
Corporate Governance, Bangladesh, accountability, agency theory, shareholders, whistleblowing
\end{abstract}

\begin{abstract}
Corporate Governance has become one of the most important strategic tools for enterprises and organizations to increase both stakeholders' value and a firm's performance. It ensures the accountability and responsibility of the directors, managers and others who hold key positions of responsibility. It is based on a set of rules and principles, processes and mechanisms by which the affairs of the corporations and firms are directed, managed and controlled. Over the past thirty years the concept of corporate governance has received substantial attention from regulatory bodies, scholars and practitioners worldwide as it has been viewed as one of the most important tools for the progress and prosperity of corporations. However, the concept is still in its infancy in Bangladesh and thus is not as well established and commonplace as it might be elsewhere.

The main purpose of this study is to understand the nature of corporate governance, its importance, need and its practices in Bangladesh within the Banking and Finance sector. The study is mainly based on secondary sources of data and information that includes scholarly journal articles, books, the Corporate Governance Act of Bangladesh 2004, and other relevant sources pertaining to the subject.

A wide range of factors, including codes of corporate governance, legal and regulatory frameworks, development of the capacity of boards of directors, introduction of good governance and institutional capacity building have been recommended to institutionalize and improve corporate governance in Bangladesh. Issues such as whistleblowing and the efficacy of Bangladesh's Legal system are germane to discussions within the ambit of this research.
\end{abstract}

Corresponding author: Raju Mohammad Kamrul Alam

Email address for corresponding author: rajukamrul@gmail.com

First submission received: $8^{\text {th }}$ January 2018

Revised submission received: $6^{\text {th }}$ August 2018

Accepted: $17^{\text {th }}$ September 2018

\section{Introduction}

Corporate Governance can be understood as a set of processes, rules and regulations, principles and guidelines by which all activities of a corporation or a firm are governed, directed, managed, and controlled. An effective corporate governance structure can enhance organizational performance by increasing stakeholders' value as it can increase the responsibility, accountability and transparency throughout the organization. It is not only increasingly becoming the required condition for corporations for their sustainable growth and prosperity, but also the most valuable strategic concept for the shareholders and other stakeholders to maintain organizational impartiality, fairness, accountability and transparency. For the past three decades we have witnessed different types of uncertainty, volatility in the global business environment. Since 1990 there have been several high-profile corporate scandals and collapses in North America, Europe and some Asian countries. The ramifications of scandals and mismanagement in entities such as Enron, Lehmann Brothers and WorldCom in the USA, Glitnir, Kaupthing and Landsbanki banks in Iceland, Royal Ahold (Koninklijke Ahold NV) in the Netherlands, 
Barings Bank in the UK and the Satyam scandal and Ketan Parekh scam in India has been considerable. Inadequate corporate structures and governing policies were the main causes of these corporate failures (Mallin, 2003). Since then, the concept of corporate governance has received considerable attention from scholars, policy makers, government and regulatory bodies (Khan, 2011; Sarker 2014).

The need for this transparent corporate structure in Bangladesh has become a necessity, particularly following a series of high-profile corporate scams within the banking and finance sector. Scams and corporate governance failures such as that of the Hallmark-Sonali Bank Loan Scam involving Sonali Bank, the largest State-Owned Commercial Bank in Bangladesh, scandals concerning Oriental Bank and Farmers Bank and issues over corporate impropriety involving the Stock Market and Foreign Exchange Reserve have generated trenchant criticism both inside Bangladesh and further afield. Therefore, corporate governance is not only about the ways in which a corporation is managed and administered but also the ways it monitors the policies and practices, decisions and actions of the corporation, their agents and stakeholders. Such an approach can lead to greater transparency, efficiency and effecting the functioning of a corporation. The core objective of the corporate governance is to increase long-term shareholders value and at the same time protecting the other stakeholder's interest (Malling, 2003) whilst ensuring corporate probity. Despite its value to organizations and the nation too, the concept and its practices are not well developed in Bangladesh, essentially it remains in its infancy. However, since the introduction of the Corporate Governance Act 2004, it has been gradually introduced in many large organisations (Haque and Arun 2016) and furthermore organizations have started to see the positive impact of corporate governance on the performance and optimization of organizational values (Shobod, Saiful, and Anup 2015); Rouf (2012); Rashid., Zoysa., Lodhh and Rudkin (2010).

The main purpose of this study is to understand the nature of corporate governance and its practices in Bangladesh, with reference to financial institutions. Also, the study highlights the need for, and importance of corporate governance in Bangladesh.

\section{Literature Review}

Corporate governance is a multi-faceted subject and is a strategic concept for enhancing organizational value and performance. There is no single and universal definition of corporate governance (Khan, 2011; Thapar and Sharma, 2017), rather it is viewed from different perspectives. According to Garvey and Swan (1994) corporate governance determines the ways management direct, manage, administer and control the activities of an organization. Shleifer and Vishny (1997) asserted that the concept should be understood by the ways in which suppliers of finance to organizations assure themselves of an increased probability of a return on their investment. The Organization for Economic Cooperation and Development defines Corporate Governance as a "system by which organisations are managed, governed and controlled (OECD, 1999). However, the OECD definition is narrow in scope as it does not consider the societal elements such as stakeholders' interest. Shliefer and Wolfenzon (2002) observed that a good corporate governance structure protects outside investors (shareholders) from inside investors (managers). According to Cadbury (2000), corporate governance is the mechanism used to discipline organizations. In 2000, Cadbury stated at the "Global Corporate Governance Forum" that corporate governance is primarily about maintaining the balance between economic and social goals. The purpose is to align the interests of individuals, organisations and society at large as much as possible.

Likewise, Morin and Jarrell (2001), argued that corporate governance is a framework that controls and safeguards the interest of the relevant actors in the markets. The best corporate governance practices improve overall accountability and performance throughout organizations. According to Beiner, S., Drobetz, W., Schmid, M., and Zimmermann, H (2004) a good corporate governance mechanism has a positive impact on the performance of the listed companies and increases the value of firms. The distribution of managerial rights and responsibilities among different actors in the organization such as boards of directors, managers at different levels, shareholders, auditors and other stakeholders are defined by the corporate governance structure. However, one of the most important definitions of Corporate Governance is given by the Ministry of Finance, Singapore which helps define the true notion of the concept as follows: "a set of processes and structure by which all affairs of an organization are managed, directed and controlled for enhancing long-term shareholders value and stakeholders' interests 
through enhancing corporate accountability and performance". The corporate governance principles should be based on four important and interrelated elements: Accountability, responsibility, transparency and fairness (Moudud-ul-Huq, 2014). The OECD (1999) identified the following key principles: (a) It should protect the shareholders' rights, (b) All shareholders should be treated equally (equitable treatment), (c) Recognition of the rights of stakeholders and that should be protected by law, (d) Disclosure and transparency, (e) The responsibility of the board.

\section{Corporate governance \& Agency Theory}

Jensen and Meckling (1976) defined the agency relationships as "a type of contact in which the main actor (principal) allows the agent to perform the organizational services on behalf of the principal". As there is a concept of delegation by principal to the agent, problems arise due to the differing interests and the conflict between these parties (principal and agent). However, these problems are not the same across the firms and sectors or industries (Himmelberg, C.P., R.G. Hubbard and D. Palia, 1999). Jensen and Meckling (1976) asserted that the value maximizing decisions are reduced by this type of delegation of authority by managers in an organization. By extending the original theory of Jensen and Meckling (1976), McColgan (2001) asserted that an effective corporate governance structure can help to reduce such agency problems.

Agency Theory recommends the involvement of independent non-executive directors to monitor any self-interested actions by managers and as a means to minimize agency costs (Walters and Kroll 2006; Williams. D., Duncan, W., Ginter, and Shewchuk R., 2006). Although the executive directors have specialized skills, expertise and valuable knowledge of a firm's activities, there is a demand for the independent directors to contribute in the field of idea generation, independence, objectivity and expertise knowledge (Weir 1997). By reviewing the various challenges and issues of corporate governance in an African context, Okeanhalam and Akinbode (2003) pointed out that many organizations in past have manifested failing or collapsed in Asia and USA due to inadequate corporate governance structures. They suggested that African organisations can learn from the past failures that have happened elsewhere. Their findings suggest that only the implementation of adequeate and appropriate corporate governance structures in an organization can help to reduce the problems between principal agents and shareholders' interests. A study conducted by Farinha (2003) to understand the consequences and nature of corporate governance with reference to the ownership problems between principal agents (managers/directors) and shareholders provides food for thought. This study identified risk preferences as one of the most important sources of conflict between these parties. While managers are concerned with the company risks as their survival depends on this risk, the shareholders are mainly concerned with the risk of stock and market risk. They suggested that an external disciplining device can reduce such problems in the organization. This is possible through the implementation of a corporate governance structure that should include the composition of board of directors, inside ownership maximization, increase the number of shareholders and appointment of independent auditors among others.

Within the context of Bangladesh, a study conducted by Moudud-Ul-Hoq (2014) on the state of corporate governance in the banking sector elucidates some key indicators. To measure the corporate governance status, they have used five specific indicators such as nature of compliance, Independent Directors (ID), Board of Directors (BOD) and its functionalities, Audit Committee (AC) and Transparency and disclosure. Their findings indicate that most of the banks are reluctant to appoint independent directors and unwilling to include independent directors on the audit committee. The nature of compliance has now improved in the banking sector and one of the possible reasons for this has been the introduction of revised guidelines by Securities Exchange Commissions in 2006. All banks are required to adopt these guidelines as a benchmark to measure the status of corporate governance. The same improvements have also been identified in the domain of transparency and disclosure. Their findings indicate that although there are some areas of improvements, Bangladesh is still lagging behind other regional states and economies of a comparable size. La Porta, R., F. Lopez-de-Silanes, A. Shleifer, and R. Vishny, (2002) conducted a study based on the sample of 539 organisations from 27 countries. Significantly, their study found that the better protection there is of minority shareholders the greater the positive impact on a company's valuation. 
A board of directors is a key mechanism for the appropriate functioning of an organization. The board of directors is not only responsible for monitoring the behavior of the management but is also accountable to an organization's stakeholders. The size of board is also significant for effective performance of an organization. Beiner, S., Drobetz, W., Schmid, F., and Zimmermann, H., (2004), Dehaene, De Vuyst and Ooghe (2001), found a positive relationship between the size of board and the performance of a company. According to Goodstein, J., K. and Boeker, W., (1994), Uadiale (2010), a large board size is believed to be beneficial for organizations as it saves valuable resources and can help reduce uncertainty. On the other hand, a small size of board is believed to improve the performance of the firm (Yoshikawa and Phan, 2003) as they highlighted that larger boards tend to be less cohesive and more difficult to coordinate because there might be diverging views and factionalism and conflict among group members. This view is reinforced by the opinions of Mark and Kusnadi (2005), who argue that small boards are more positively associated with high performance. Lipton and Loarch (1992), suggest an optimal board size between 7 to 9 directors. Having an odd number is significant as it ensures that when votes take place that ties are less likely.

Another important aspect of the corporate governance principle is the Audit Committee (AC). The role of an audit committee is important in improving the performance of a company or organization. According to the Securities and Exchange Commission (SEC) Rule (2012), an audit committee should work independently and perform their duties with professional care. An Audit Committee is a monitoring mechanism that in theory should help increase the quality of information. Mansi, S.A. and Reeb, D. M., (2004), reported a positive relationship between an audit committee and an organization's performance. On the other hand, Kajola (2008), shows there are no significant relation between audit committee and a company's performance.

The practices of corporate governance are essential for effective, competitive, safe and sound financial and banking institutions and to stimulate and support the economic growth through the efficient allocation of resources.

\section{Corporate Governance in Bangladesh: Banking and Finance sector}

Most companies depend on banks as their chief source of finance. In Bangladesh, the capital market is still in an emerging state with market capitalization amounting to a mere $6.5 \%$ of GDP with low investor confidence in corporate governance and financial disclosure practices in many companies listed on the Stock Exchange (Hua. 2006). Bangladesh, like many other developing countries, has been experiencing broad-based corporate governance reform initiatives since 2001 under the guidance and sponsorships of international financial institutions such as the World Bank (WB), the International Monitory Fund (IMF), and the Asian Development Bank (ADB) (Haque and Arun 2016). Following this, the regulatory authority of Bangladesh introduced a code of corporate governance that sets out the principles, procedures and processes of corporate governance practice in 2004. Subsequently, it has been a requirement for the financial institutions and banks to adopt the corporate governance practices and procedures as a measure of benchmarking. Corporate governance in Bangladesh is shaped by several guidelines: (a) Company law, (b) Bangladesh Bank guidelines, (c) Securities and Exchange Commission (SEC) guidelines, and finally (d) peer pressure (Moudud-Ul-Huq, 2015). Whilst these four dimensions have resulted in change there is a general consensus that they are still not enough, and that Bangladesh lags behind its Asian and international competitors. Ahmed and Yusuf (2005), argue that there has been failure in most of the elements of corporate governance. According to them one of the main reasons for such poor corporate governance practices in Bangladesh is due to the dominance of family-oriented businesses, weak regulatory system, inadequate bankruptcy laws, the influence of top management, fraud and corruption, lack of initiatives to drive corporate governance from international investors community, and political pressure. Some other factors are:

1. Inconsistency between the Companies Act, Bangladesh Accounting Standards (BAS) and SEC requirements: (Ahmed \& Yusuf 2005). The Company Act, 1994 provides among other things for provision regarding preparation and publication of financial systems, disclosures and auditing. However, in many cases, the Act lacks clarity with regards to statutory requirements on disclosures in the financial statements of listed companies (Moudud-Ul-Huq, 2015; Sarkar, 2014) 
2. Limited or no disclosure regarding related party transactions: Related party transaction is not disclosed properly in the financial statements. This is a serious barrier when it comes to achieving corporate governance in Bangladesh (Sarkar, 2014).

3. Capital market role: Tadesse (2004) asserts that adequate production of information and monitoring systems can help facilitate good governance. However, the capital market in Bangladesh is still a weak link that requires attention to strengthen corporate governance. The overall performance measures of its stock market show low trade volumes and intermittent turbulence.

4. Board committees: In corporate governance, board committees (audit, remuneration and nomination) are very important. An audit committee is treated as a principal player in ensuring effective corporate governance and can play a key role in helping to rebuild public confidence in financial reporting. However, most of the listed organisations do not have any monitoring and remuneration committees, only a few boards have an audit committee and some of these are decidedly supine in nature.

5. Lack of Shareholder Activism: Shareholder rights are recognized across the globe as pertinent to efforts for enhancing and strengthening corporate governance. This is clearly indicated in the OECD Principles (1999) and these have been adopted in organizations throughout developed countries. However, in Bangladesh, the average non-controlling or minority shareholders do not possess significant levels of education, understanding and sophistication required to exert pressure on a company to change behavior. The number of shareholders with adequate knowledge and skills to understand company operations and to hold management and the board of directors accountable is very low. Furthermore, general shareholders do not pay sufficient attention to issues of performance, business strategy, future business plans, disclosures and processes that could give them a greater voice in the policy decisions of a company. In fact, in Bangladesh there is very little awareness of shareholders' rights and responsibilities. Shareholders' activism is still an illusion (Hossain 2015).

6. Lack of Auditor Independence: Auditors in Bangladesh are not considered independent or sufficiently qualified to attest to the validity of the financial statements of corporate entities (Bangladesh Enterprise Institute 2003). A study conducted by Raihan in 2003 showed that 64.4\% of the companies conduct regular audit for effective implementation of the core labour policies. Of the companies which audit the implementation of core labour policies, $91.1 \%$ met their labour policy objectives. Only $2.2 \%$ of the companies admitted that they carry out unfair dismissals and $4.4 \%$ of the companies admitted that they had violated labour laws over the previous five years. Around $67 \%$ of companies have a formal Health \& Safety policy to ensure clean, healthy and safe working conditions. Procedures to implement policy and specific assignment to senior management for implementation were found in only $26.7 \%$ of companies.

7. Poor Audit Reporting: Audited financial reports are rarely reliable and free from the malign influence or control of the owners of the company's being audited. Despite irregularities in the audit report, the auditors issued unqualified audit report on the financial statements. Matters are not helped by the fact that in Bangladesh there is a shortage of accountants with specialist knowledge of forensic accounting.

8. Weakness in the Judicial System: The wheels of justice turn notoriously slowly, and this has a direct bearing on cases concerning corruption and suspected financial impropriety. Concerns have been raised in certain quarters that laws have failed to keep pace with the increasingly complex nature of serious fraud in a globalized economy. Furthermore, rates of successful prosecution in respect of fraud and corruption cases remain low, with the added complication that the Bangladesh Judicial System is periodically tainted by the politicization of the judiciary and attempts by successive executive branches of government trying to manipulate it or bring pressure to bear (Panday \& Mollah, 2011).

Nevertheless, the past few years have witnesses a greater inclination towards corporate governance due to a variety of forces such as deregulation in the financial sector and economic liberalization, 
institutionalization of capital markets, globalization, market competitiveness, standards of disclosure and media and social media scrutiny.

According to the Securities and Exchange Commission Rules (2012), at least one fifth of the total number of directors in a company's board should be independent directors. The main role of an independent director is to monitor and control a company's activities effectively, thus potentially helping to provide a safeguard against internal managerial fraudulent activities. The proportion of independent directors is positively correlated to the performance of the firm. Rashid, A., Zoya, A. D., and Rudkin, K., (2010), Kajola (2008), and Moscu (2013) have concluded that the independent directors cannot add potential value to the economic performance of organizations. Some researchers found that although the proportion of independent directors on the board is high, the level of board independent and professionalism is not necessarily good (Chen, K.y., Elder, R. and Hseh, M., 2007). Thus, the message in this respect is decidedly mixed.

The rules further explain that the positions on the Board and CEO should be filled by different individuals as their function is not necessarily separate. Duality occurs when one individual holds the two most powerful post of CEO and Board chairman (Weir and Laing, 2001). The separation of the two positions creates necessary checks and balances over their performance. The results of the study of Klein (2002), suggest that boards that are separated from the CEO are more effective in monitoring the corporate financial accounting process. Separation of board chair from CEO basically reduces agency costs for a firm (Coleman and Osei 2007). Kajola (2008), found a positive and statistically significant relationship between performance and separation of board chair and CEO.

Despite various regulations for the financial institutions to implement corporate governance codes in Bangladesh, progress and success remains decidedly patchy. There are many forces of resistance within the sector. According to Mueen (2007) resistance comes mainly from vested interests who want to maintain the status quo. There is a tendency in Bangladesh to make large investments in highly capitalintensive enterprises with an eye to price incentives through relationships, this leads to wastage of scarce capital resources. To finance expenses, many firms now need foreign capital which can lead to demand for greater transparency and better corporate governance. In Bangladesh vested interests and a highly charged political dynamic are the key factors that hinder the process of any good governance framework. Thus, policy makers need to focus on both regular financial accounting and transparency, whilst also addressing thorny issues such as whether a large business group should also be allowed to have their own bank. Currently, there are many issues that impede the enforcement of corporate governance in Bangladesh. Some of these are: (a) The board of directors: Lack of power by the head of the Institution/CEO and unwillingness to appoint independent directors, an absence of accountability mechanisms within the organization; (b) Accountability and Monitoring: Difficulty in accessing the actual information, management collusions with trade unions, commercial audits are doubtful in many cases; (c) Commercial focus: Non market driven price mechanisms, unfair competition from the private sector; (d) Poor employee incentives: No genuine incentives for the employees for better performance, poorly designed remuneration package, pressure from trade unions, and malfeasance by those persons who have a duty to ensure that the law is upheld and that codes are enforced. e) Nepotism and appointments, promotion and preferment that is not based on merit: Across all sectors there are legitimate concerns about the fact that individuals occupy roles not on their qualifications, experience or what they know and can contribute, but on who they know, have bribed or who they happen to be related to.

\section{Methodology}

The study is purely based on secondary sources of data that include scholarly journal articles, conference proceedings, relevant books, corporate governance guidelines and code of practice produced by concerned bodies such as Bangladesh Bank (BB), Securities and Exchange Commission (SEC), the Code of Corporate Governance for Bangladesh, Bangladesh Enterprise Institutes (BEI) guidelines and OECD principles of corporate governance. 


\section{Findings and discussions}

Based on the current and relevant literature of corporate governance and various corporate governance guidelines and codes of practice introduced by regulatory bodies in Bangladesh and elsewhere, the study found that the concept has received substantial attention worldwide over the last thirty years and increasing attention in Bangladesh over recent years. This interest has become more pronounced following a series of high-profile corporate scandals and failures worldwide that includes scandals in financial institutions in Bangladesh. There are a range of corporate governance guidelines and codes of practice introduced by regulatory bodies in Bangladesh such as Bangladesh Enterprise Institute (BEI) which introduced the Corporate Governance Codes in 2004. The Securities and Exchange Commissions (SEC) introduced Corporate Governance Guidelines in 2006 and asked financial institutions and all listed companies to adopt these guidelines mandatorily as a benchmark for measuring corporate governance status within the organization. The issue of corporate governance and its practices came to public prominence when the Bangladesh Central Bank had to take over the Oriental Bank in 2006 due to a serious liquidity crisis.

It is evident that since the introduction of corporate governance guidelines by the SEC, various listed organizations have started, albeit sometimes rather reluctantly, to adopt various corporate governance principles within their organizations. However, the practices are often far from comprehensive and satisfactory. The study identified the following areas that require attention in order to expedite the implementation of corporate governance practices in Bangladesh within the banking and finance sector:

1. Appointment of independent directors: SEC guidelines indicate that at least one tenth of the company`s directors should be independent and independent director should be appointed by the elected directors and this should be approved by the shareholders at the annual general meeting (Zaman and Quazi, 2015). However, most of the banks do not follow this guideline. Although some banks appoint an independent director, but the appointment process is not included in the company`s annual financial report (Sarkar, 2014).

2. The role of Audit Committees: Although, many banks are not willing to include an independent director in the audit committee, after the introduction of revised guidelines by SEC in 2012, many listed organizations have been complying with these guidelines.

3. Board composition and size: According to SEC guidelines, 5-20 should be the ideal size of the board of directors of a corporation. Study conducted by Sarkar (2014) found that DBBL (Ductch Bangla Bank Limited) comply the SEC guidelines. DBBL had 9 directors in 2009 including 4 nonexecutive directors. In relation to the audit committee, board size and voluntary disclosure, study conducted by Rouf (2010) observed that a positive association between board size, audit committee and voluntary disclosure.

4. Appointment of CEO and Chairman/Chairwoman; According to the revised SEC guidelines 2012, the separation between the roles of CEO and Chairman of the company is vital and required. The study observed that a number of banks currently are complying with this guideline, such as DBBL (Butch Bangla Bank Ltd) and this support the findings of Rouf (2010), Sarkar (2014)

5. Lack of transparency towards shareholders: Findings suggest that as the concept is in infancy in the context of Bangladesh, despite various guidelines introduced by regulatory bodies, the applications of corporate governance principles are still unsatisfactory and there remains a degree of reluctance on the part of companies. Many financial institutions and banks are still not clarifying the roles and responsibilities of the board. Management consistently fail to provide transparent information with accountability to the stakeholders. Some companies' financial integrity is questionable. On occasions shareholders do not have clear and clear information on a whole range of activities of the organization. Previous studies support the findings (Shobha and Kalaivani, 2014; Sarkar, 2014).

6. Lack of enforcement and monitoring systems: Weak regulatory system have been found to be a barrier for achieving sound corporate governance. Laws are flouted and not enforced effectively.

7. Poor financial reporting system: The financial reporting system in Bangladesh is still not fully standardized. A robust regulatory regime and enforcement mechanism are both lacking and not 
effectively applied. Disturbingly in many cases auditors are not independent. The findings are in the line with the research of Mahmud and Ara (2015)

\section{Recommendations}

The following recommendations can be put forward to implement reforms in corporate governance with a view to ensuring robust corporate governance in Bangladesh:

1. Code of Corporate Governance: Bangladesh needs to have a "Code of Corporate Governance and Best Practice Recommendations" which can be either rule based, or principles based. For Corporate Governance, Bangladesh Enterprise Institute (BEI), Bangladesh Bank (BB), and SEC have developed separate Codes of Corporate governance practice. By making necessary changes in the Companies Act the Government must take initiatives to make sure that these are both widely known and properly implemented.

2. Implementing Competition Policy: An effective competition policy invariably yields a more flexible, dynamic, and competitive private sector that in turn leads to sustained and widely shared economic development. Bangladesh needs to formulate a Competition Policy that assures a culture of strong corporate governance that becomes embedded and reflective. Competition policy helps bring about greater efficiency, promotes greater accountability, helps to reduce price distortions, lowers the risk of poor investment decisions, and increases transparency in business decisions, and lead to better corporate governance (BEI 2004).

3. Robust legal and regulatory framework: The legal and regulatory framework should ensure that non-controlled or minority shareholders are protected from exploitation by insiders and controlling or sponsor shareholders. The Government should introduce measure or enhance existing measures to strengthen disclosure mechanisms, compliance systems throughout the organizations, establishing shareholders rights and director's accountability and responsibilities.

4. Improve the Capacity of Board of Directors: From the outset it is vitally important that goals are aligned and that there is an appreciation of the fact that invariably on any Board of Directors there are different aversion levels to risk, hence the relevance of Agency Theory. The directors should commit to promoting participation in strategic planning, monitoring of internal control systems as well as the independent review of transactions involving managers, controlling shareholders and other insiders. It is imperative that there is director training, expectations for professional conduct, voluntary codes of conduct and authority vis-à-vis management. Clear parameters need to be set with an emphasis on addressing matters that might appear ambiguous. It is also required to minimize or eliminate loopholes by tightening standards for director 'independence' by making 'shadow' directors liable for their actions, by increasing sanctions for violations of duties of care as well as by advocating delineation of a core set of related-party transactions that should be outright prohibited. It is significant to facilitate mechanisms to adequately empower the shareholders to seek redress for the violation of their rights and to ensure accountability of director. The two most important things that can ensure good corporate governance are high standards of ethical and personal conduct. High standards can only be ensured if the value system of society instils these in citizens as the norm in every aspect of life. Good corporate governance must become an unshakable social and moral imperative (Hossain 2015).

5. Monitor and Enforce the Implementation of Corporate Governance: The Securities and Exchange Commission of Bangladesh needs to be strengthened so that it can devise and enforce a code for good corporate governance. The Companies Act requires updating to be consistent with the Bangladesh Accounting Standards (BAS), SEC requirements and the Bank Companies Act. For all listed companies, independent Audit Committees should be made compulsory. A healthy corporate governance environment will prevail in Bangladesh through the policymakers implementing the recommendations suggested above (Ahmed \& Yusuf 2005). Ensuring that there are an adequate number of personnel with suitable training and resources is integral to success.

6. Public-Private Partnership (PPP): Both Public and Private institutions should continue to raise awareness among companies, directors, shareholders and other interested parties of the value of good corporate governance. It requires not only a strong national commitment, but also a 
committed board to achieve the desired corporate governance framework in Bangladesh. Knowledge sharing is vital, and the public and private sector would do well to forge meaningful links as well as engineering opportunities to learn from one another.

7. Commence good governance practice in state owned enterprises: With a view to providing a strong demonstration effect, corporate governance reforms in strategic state-own enterprises (SOEs) that handle energy supply, telecommunication as well as air transportation can be undertaken. There is considerable potential to help state-owned enterprises to become beacons of exemplary practice.

8. Institutional Capacity Building: The enabling of a sound framework for corporate governance requires the dissemination of corporate governance and enterprise restructuring principles. Public awareness and development of governance structures for example, enforceable regulations, ensuring financial transparency, combatting financial malpractice and any form of market manipulation are essential for that. Thus, it is important to educate the public about their rights as shareholders and about the work of modern corporations through the specialized publications as well as national and regional media. Social media is a powerful means for engagement and articulation.

9. Quality improvement of financial reporting: The quality of financial reporting needs to be improved in Bangladesh. A robust regulatory regime and effective enforcement of the accounting and auditing standards are required for that to take place. The genuine independence of the auditor is at the crux of effective corporate governance. Auditors need to be able to carry out their work without fear or favour. Auditors require monitoring through strict enforcement of the professional code of ethics of auditors, with safeguards for whistleblowers and a clear disciplinary process that involves the threat of legal action for those engaged in serious and sustained breaches of professional standards and or the law. If auditors fail to act independently, overtime trust will be eroded, and they will cease to be relevant as a bulwark against corporate/financial impropriety.

10. Whistle Blower Protection: A powerful signal of the national commitment to addressing fraud, corruption or mismanagement would be the formulation and passage into law of a Whistle Blowers Protection Act. This should cover both the public and private sector and include suitable safeguards and punishments for those who might engage in vexatious or frivolous complaints. Bangladesh might wish to emulate or seek inspiration from the Whistle Blowers Protection Act, 2011 that is an Act in the Parliament of India. Whistleblowers have a constructive role to play in Corporate Governance and developing clear procedures about such activity helps connote a commitment to transparency and bolsters trust (Callahan et al, 2002).

\section{Limitations of this study and scope for future research}

A purely theoretical paper of this nature has value for practitioners, and yet such is the dynamic nature of Corporate Governance that there is much to be gained from undertaking an empirical study that is anchored in findings collected via the use of a survey. The lion's share of research that focuses on Bangladesh tends to be Dhaka-centric, and thus it is important to ensure that businesses outside of the Bangladeshi capital are not overlooked or forgotten. Attitudes and approaches to Corporate Governance are not the same across the globe, hence there is merit in taking greater cognizance of cultural factors, and in this regard, there is potentially some value to be gained by examining Geert Hofstede's 6 dimensions model of national culture in respect of Bangladesh. Additional research could be undertaken to examine the local composition of Boards of Directors and the degree to which those who sit on them are prepared for the task and given appropriate guidance and ongoing training. A perennial concern is the degree to which boards are often perceived as being reactive rather than proactive, hence the desirability of further research that examines the factors that help create an environment where Corporate Governance thrives. The role of business and leadership education in enhancing the understanding of business ethics and the pivotal role that Corporate Governance can play in Bangladesh is worthy of consideration. Another possible future avenue of research could be an exploration of the part played by local higher education providers, both public and private, in helping spread and embed a wider appreciation of Corporate 
Governance as a central mechanism for effectiveness and greater transparency both in banking and finance and other fields of human endeavor.

\section{Conclusion}

This research confirms the growing appreciation of Corporate Governance, whilst acknowledging that in a Bangladeshi context there are limitations in coverage and application. The degree to which Corporate Governance in Bangladesh remains in its infancy is open to debate, sectors vary considerably and yet there are signs that the subject itself is receiving greater attention. In identifying some of the most common weakness and areas of concern this paper has endeavoured to elucidate what requires attention, along with elements that might enable positive and purposeful development. As a country Bangladesh can benefit tremendously from benchmarking against what is helping elsewhere. Corporate scandals serve as an important reminder that there is no room for complacency and that it is better to be proactive rather than merely reactive. Additional research would improve general understanding of Corporate Governance and help shed light on the way in which enterprises in Bangladesh are receptive to best practice. Finally, it is important to acknowledge that whilst effective Corporate Governance is not a panacea for all corporate ills, it has a key role to play and as such warrants greater attention and action.

\section{References}

Ahmed, Mamtaz Uddin, and, Yusuf, Muhammad Abu (2005). Corporate Governance: Bangladesh Perspective. The Cost and Management. Vol. 33. No. 6. November-December 2005. pp. 18-26.

Anderson, R. C., Mansi, S. A. \& Reeb, M. A. (2004). Board Characteristics, Accounting report integrity and the cost of debt. Journal of Accounting and Economics, 37.

Bangladesh Enterprise Institute (2004). Code of Corporate Governance for Bangladesh. Dhaka: BEI. www.bei-bd.org

Beiner, S., Drobetz, W., Schmid, M., and Zimmermann, H (2004), An Integrated Framework of Corporate Governance and Firm Valuation - Evidence from Switzerland, ECGI working paper series in Finance, Working paper no: $34 / 2004$

Cadbury Committee. (1992). Cadbury Reports, London Stock Exchange, London

Cadbury, S. A. (2000). The Corporate Governance Agenda, Corporate Governance: An International Review, 8 (1), pp. 7-15.

Callahan, E. S., Morehead, T., Dworkin, Fort, T. L., \& Schipani, C. A. (2002). Integrating trends in whistleblowing and corporate governance: Promoting organizational effectiveness, societal responsibility, and employee empowerment. American Business Law Journal, 40(1), 177-215.

Chen, K.Y., Elder, R. and Hsieh, M., (2007). Corporate governance and earnings management: The implications of corporate governance best-practice principles for Taiwanese listed companies. Journal of Contemporary Accounting \& Economics, 3, pp.73-105.

Coleman, A.K. and Osei. K. A., (2007). Outreach and profitability of Microfinance Institutions: the role of governance. Journal of Economic Studies, 35 (3), pp.236-248

Dehaene, A., De Vuyst, V. and Ooghe, H., (2001). Corporate Performance and Board Structure in Belgian Companies. Long Range Planning, [e-journal] 34(3), pp.383-398, [Abstract only]. Available through:

https://doi.org/10.1016/S0024-6301(01)00045-0. [Accessed 3 September 2017].

Garvey G T., and Swan P L (1994), The economics of corporate governance: Beyond the Marshallian firm, Journal of Corporate Finance, Vol. 1 Issue 2, pp 139-174

Goodstein, J., Gautam, K. \& Boeker, W., (1994). The Effects of Board Size and Diversity on Strategic Change. Strategic Management Journal, 15, 241-250.

Hua, DU (2006). Roundtable Discussion on Corporate Governance Guidelines of SEC and its implementation practices in Bangladesh. Asian Development Bank. 23 September 2006.

Haque, F. and Arun, T.G., (2016). Corporate governance and financial performance: an emerging economy perspective. Investment Management and Financial Innovations, 13(3), pp.228-236. [18]

Hossain, M. (2005). Why shareholders' activism is still an illusion in Bangladesh. The Financial Express, Dhaka (1-82005).

Himmelberg, C.P., R.G. Hubbard and D. Palia. (1999), “Understanding the determinants of Ownership and the link between Ownership and Performance", Journal of Financial Economics 53, 353-384.

Hussain, M. (2015). Effective fraud risk management in banking sector. The Financial Express [online] 19 April 2015

. Available at: http://print.thefinancialexpressbd.com/2015/04/19/89309

Jensen, M.C. and W.H. Meckling. (1976), “Theory of the Firm: Managerial Behaviour, Agency Costs and Ownership Structure", Journal of Financial Economics 3 (4), 305-360. 
Kajola, S. O., (2008). Corporate Governance and Firm Performance: The Case of Nigerian Listed Firms. European Journal of Economics, Finance and Administrative Sciences, 14, pp.16-28.

Klein, A., (1998). Firm performance and board committee structure. Journal of Law and Economics, 41(1), pp.275- 303.

La Porta, R., F. Lopez-de-Silanes, A. Shleifer, and R. Vishny, (2002), Investor protection and

corporate valuation, Journal of Finance 57, 1147-1170.

Lipton, M. and Lorsch, J.W., (1992). A modest proposal for improved corporate governance. Business Lawyer, 48(1), pp.59- 77

Mak, Y. and Kusnadi, Y., (2005). Size really matters: further evidence on the negative relationship between board size and firm value. Pacific- Basin Finance Journal, 13(3), pp.301- 318.

Thapar, M and Sharma, A (2017), Corporate governance in India: An analysis, Journal of Economic and Social Development - Vol 4. No 1., March

Mahmud S and Ara Jesmin (2015), Corporate governance practices in Bangladesh an overview of its present scenario in banking industry, International Journal of Economics, Commerce and Management, Vol. III Issue 12

Mallin, A. C. (2003). Corporate governance. Oxford University Press, New York.

McColgan P., (2001), "Agency theory and corporate governance: a review of the literature from a UK perspective", Department of Accounting \& Finance, University of Strathclyde, Glasgow.

Moudud-Ul-Huq (2015), Corporate governance practices in Bangladesh: A comparative analysis between conventional banks and Islamic banks, International Journal of Management Business Research, January, Winter

Morin, R. and Jarrell, S., (2001), Driving Shareholders Value: Value-Building Techniques for Creating Shareholder Wealth, McGraw-Hill Publishers, Sydney.

Moscu, R. G., (2013). The Relationship between Firm Performance and Board Characteristics in Romania. International Journal of Academic Research in Economics and Management Sciences, 2(1), pp.167-175.

Mueen, Afzal (2007). Role and Responsibilities of Independent Directors. Key note paper. Roundtable discussion on the Role and Responsibilities of Independent Directors. Bangladesh Enterprise Institute. March 18, 2007.

Okeahalam C., and Akinboade. O. A., (2003), "A Review of Corporate Governance in Africa: Literature, Issues and Challenges", Global Corporate Governance Forum.

OECD (1999), OECD principles of corporate governance. Meeting of the OECD council at Ministerial level

OECD. (2004). OECD Guidelines on Corporate Governance of the State-owned Enterprises. OECD: Paris

Panday, P. and Mollah, A., (2011) "The Judicial System of Bangladesh: An Overview from Historical Viewpoint", International Journal of Law and Management 53(1), pp. 6-31

Raihan, Ananya (2003). Corporate Responsibility in Bangladesh: Where Do We Stand? Report No. 54. Centre for Policy Dialogue: Dhaka. www.cpd-bangladesh.org

Rashid, A., Zoysa, A. D., Lodh, S. and Rudkin, K., 2010. Board Composition and Firm Performance: Evidence from Bangladesh. Australasian Accounting Business and Finance Journal, 4(1), pp.76-95.

Rouf, A. (2010). Corporate Characteristics, Governance Attributes and the Extent of

Voluntary Disclosure in Bangladesh. Asian Journal of Management Research, 166-183.

Rouf A., (2012). The Relationship between Corporate Governance and Value of the Firm in Developing. Journal of Economics and Business Research 1, pp.73-85

Rouf, Md., (2012), The Financial Performance and Corporate Governance Disclosure: A Study in the Annual Reports of Listed Companies of Bangladesh. Pakistan Journal of Commerce and Social Science, Volume-6, Number-1, pp01-11. Available at SSRN: https:/ / ssrn.com/abstract=2568478

Sarker S H (2014), Scenario of Corporate Governance Practices in Bangladesh: A Study on Dutch Bangla Bank Limited (DBBL, European Journal of Business and Management, Vol. 6 No. 37, PP-120-126

Shleifer A. and Vishny, W. R. (1997). A Survey of Corporate Governance. Journal of Finance, 52 (2), pp. 737-783.

Shleifer, Andrei, and Daniel Wolfenzon. 2002. "Investor Protection and Equity Markets." Journal of Financial Economics 66 (1): 3-27

Shobod D N., Saiful I., and Anup K S (2015), Corporate Board Structure and Firm Performance: The Context of Pharmaceutical Industry in Bangladesh, International Journal of Economics and Finance; Vol. 7, No. 7; pp 106-115

SEC (Securities and Exchange Commission) Notification (2006). (No.SEC/CMRRCD/2006-158/Admin/02-08 dated 20th February 2006), Dhaka.

Tadesse, S. (2004). The Allocation and Monitoring Role of Capital Markets: Theory and International Evidence. Journal of Financial and Quantitative Analysis. December. Vol. 39. No. 4

Uadiale, O. M., (2010). The Impact of Board Structure on Corporate Financial Performance in Nigeria. International Journal of Business and Management, 5(10), pp.155-166.

Walters, B. and Kroll, M., (2006). The moderating effects of external monitors on the relationship between R\&D spending and firm performance. Journal of Business Research, 59(2), pp.278-287. [25] 
Weir, C. and Laing, D., 2001.Governance structures, Director Independence and Corporate Performance in the UK. European Business Review, 13(2), pp.86-94.

Williams, D., Duncan, W., Ginter, P. and Shewchuk, R., 2006. Do governance, equity characteristics, and venture capital involvement affect long-term wealth creation in US health care and biotechnology IPOs? Journal of Health Care Finance, 33(1), pp.54-71.

World Bank. (2006). Held by the Visible Hand: The Challenge of SOE Corporate Governance for Emerging Markets. World Bank: Washington. http://rru.worldbank.org/Documents/Other/CorpGovSOEs.pdf

Yoshikawa, Toru and Phan, Phillip. The Performance Implications of Ownership Driven Governance Reform. (2003). European Management Journal. 21, (6), 698-706. Research Collection Lee Kong Chian School of Business. Available at: https://ink.library.smu.edu.sg/lkcsb_research/2289, accessed on the 10th August 2018

Zaman F and Quazi Zahurul (2015), Literature Review on Corporate Governance Structure and Performance in NonFinancial Firms in Bangladesh, Asian Journal of Finance \& Accounting, Vol. 7 No. 1 